Research.

\title{
The effect of quality service and price upon the customers satisfaction (case study at TIKI branch at JI. K. H. Sholeh Iskandar Bogor)
}

\author{
Adri Wihananto \\ Department of Management, Economic College of Binaniaga, Bogor, Indonesia \\ adri.wihananto@gmail.com (A.Wihananto)
}

Received: April 25, 2019; Accepted: May 12, 2019; Published: June 30, 2019

To cite this article: Wihananto, Adri. 2019. The effect of quality service and price upon the customers satisfaction (Case study at TIKI branch at JI. K. H. Sholeh Iskandar Bogor). The Management Journal of BINANIAGA. 4 (1): 01-10. doi:

\begin{abstract}
This research aims to study the effect of quality service and price either simulatenously or partially upon the customers satisfaction at PT TIKI Branch at Jl. K. $H$. Sholeh Iskandar Bogor. Analytical technique of this research has applied multiple linear regression analysis to figure out to which extent the quality service and price either simultaneously or partially has affected the customers satisfaction. The result has indicated that quality service and price simultaneously have affected significantly the customers satisfaction. This result has depicted that the value of $F$-count is 71.270 , however Ftable df: $\alpha,(k-1),(n-k)=0.05,(2-1),(146-3)$ is 4.60 due to F-count $>$ Ftable $(71.270>4.60)$ and its sig.value of $0.000<5 \%(0.05)$.
\end{abstract}

Keywords: Quality Service, Price, Customers Satisfaction

\section{Introduction}

A rapid business development has been creating lots of new businesses established either small one, middle one or bigger one. This phenomena is followed by rapid development of courrier enterprises establishment. The availability of courrier enterprises has supported business people to ease the delivery of their goods to their customers either close to their place or far from their operational area, and of course it can enlarge their market area which will increase their profit.

It is fully aware that the quality of a service and customer satisfaction are the crucial aspects supporting such a business to survive from and to gain the competitive business. The company can survive obviously as long as it can provide a satisfied service to its customers. Customers satisfaction is a reliable weapon to win the competitive business, but on the other hand, it could be a boomerang too which could jeopardize the company itself among a complex business nowaday.

An excellent quality service of a company can make the customers satisfied, because the customers can compare the service given with other company. If the customers are satisfied, they will recommend it to other people.

TIKI Bogor branch which is located at Jl. K. H. Sholeh Iskandar having some agents has been trying to meet the requirement of the customers, but, Tiki has not yet encountered the way how to know its customers evaluating it. Referring to this phenomena the writer has tried to find out the customers feed-back about the quality of the service of TIKI Bogor Branch which locates at Jalan K. H. Sholeh Iskandar. Based on their feed-back, the weakness and strength of TIKI Bogor branch can be evaluated in 
order to understand whether its marketing strategy applied has already complied with or it has to be improved to reach the target expected.

Due to the point of view marketing, price is a monetary unit or other measurement (including goods and services) that can be exchanged to get the right of ownership or to use the goods or the services accordingly (Tjiptono, 2011) Referring to Monroe in Ellena (2011), price is a sacrified economy done by the customer in order to get a product or a service. The price is considered expensive, cheap or reasonable depends on the customers' perception which is different from one to another according to their background and condition. (Schifman and Kanuk, 2009).

Customer satisfaction is a circumstance when the goods / services received are complying with the customers' expectation. A customer who is satisfied with the value of product or service given, mostly he/she will be a loyal customer for such a long time (Umar, 2009).

In order to measure the quality of a service, according to Tjiptono, (2014: 26) it can use the dimensions of quality service such as tangible evidence, reliability, responsiveness, assurance and empathy.

This measurement is wellknown as quality service model. The service which is focusing to the consumer's satisfaction aspect will make the customers loyal to the company which has provided service of excellent for them.

The aims of this research are as follows:

1. To figure out the effect of quality service partially upon the customer satisfaction at PT TIKI Branch Jl. K. H. Sholeh Iskandar Bogor.

2. To figure out the effect of price partially upon the customer satisfaction at PT TIKI Bogor Branch Jl. K. H. Sholeh Iskandar Bogor.

3. To figure out the effect of quality service and price simultaneously upon the customer satisfaction at TIKI Bogor Branch JI. K. H. Sholeh Iskandar Bogor.

\section{Library Reviews}

\section{Quality Service}

Refers to Tjiptono (2010:59) quality service is a superior level expected and is controlling issue to meet the customer requirement.

There are five determinants to define the quality service which are as follows.

Reliability which is the ability to provide a service promised on time and trustworthy.

Responsiveness. This dimension covers a willingness to support the customers and to provide a proper and rapid service.

Assurance is the knowledge and politeness of the employees to create belief and trust, or a guarantee which is shown thru the knowledge, politeness, safety, trustworthy, free from danger and risk given to the customers.

Empathy is a willingness to give personal honesty attention to the customers and to try to understand the customers requirement.

Tangible is an effort of an institution to show off its existence to the external party.

\section{Price}

Referring to Kotler and Keller (2008:519) price is a mixed marketing element producing the revenue. However, price according to Lamb et.al (2011:268) is

Adri Wihananto. The effect of quality service and price upon the customers satisfaction (Case study at TIKI branch at Jl. K. H. Sholeh Iskandar Bogor) 
something that should have been given by the customer to get the product.

Referring to Dharmesta (2008), price is a certain amount of cash required to get such a quantity of both product and service.

\section{Role of the Price}

Price has two kind of roles required in the process of decision making done by a buyer:

a. Allocation role of the price which is the function of a price helping the buyers to decide how to get a maximum benefit expected based on their afford to buy.

b. Information role of the price is the function of price educating the consumers about the products factors, such as quality. Common perception is that expensive price means high quality. (Tjiptono, 2008:152).

\section{Price Indicator}

a. Price or tarif which is relatively standard

Relative standard price is the consumers decision to use a product. Consumers are very selective about the price offered as there are so many competitors. When the price is not meeting the consumers requirement, they will choose other company, especially when the tarif offered is not in compliance with the standard given.

b. Price is in compliance with the quality.

.Customers will find good quality of the product obviously, however, they will choose an affordable product. As a matter of fact, consumers know that they can find similar product which is affordable and the quality is not far from a branded one.

\section{c. Promotion programe or discount subcription}

Discount is a price reduction. Discount is offered to attract the customers participation to make a decision using a service (Tjiptodjono, 2013).

\section{Customers Satisfaction}

Referring to Kotler (2010:36), customer satisfaction is a customer feeling either being satisfied or disappointed due to the evaluation between expected products or services with the products / services they received.

\section{Method of Customers Satisfaction Measurement}

Tjiptono (2014:148) has identified four methods of customer satisfaction measurement as follows:

a. Complaint and Suggestion System

Each company dealing with services which is customer oriented should have given a big opportunity for the customers to give their suggestions, opinion and complaints.

b. Ghost shopping

One of the strategies to obtain a clear picture about customers satisfaction is by employing a person or persons (ghost shopper) who will be acting or pretending as the customers or potential buyers of the competitors products. Furthermore, this person will report his / her findings about the strength and weakness of the competitor products. 


\section{c. Lost Customer Service}

The company should have got in touch with its customers who have stopped buying the products or have moved to buy the products to other supplier in order to know why it has happened so that the company can perform a corrective action or a continuous improvement.

d. Survey of Customers Satisfaction

Survey, a company will get response and direct feed back from the customers and it will give positive signal mentioning that the company has obviously concerned about its customers.

The implemention of proper service patern has required a knowledge about the different perception and feed-back from the customers. Criteria about customers satisfaction upon the services given is when customers are satisfied with the services offered by the company have met their expectation.

\section{Research Method}

This research has applied descriptive quantitative method. Descriptive quantitative has described or figured out the object of the research which is data of the samples or population as it is. (Sugiyono, 2016:29). This research has also applied survey method using the regression analitical technique. This regression analytical technique is applied to obtain the information about the extent of the correlation happened between independent variable and dependent variable (Hadi, 2014:1). The research which has taken the samples from a populatiion using questionnaires as data collection instrument.

This research has used primary data received from the questionnaires distribution at the agent of TIKI delivery service company in Bogor which locates at JI. K. H. Sholeh Iskandar. Population of this research are the customers who come to the office of PT TIKI in February to March 2018 who are using the service of PT TIKI which are 203 customers. So that, defining the total of the samples, this research has applied Slovin equation, error deviation of $5 \%$ and the samples of this research are 146 customers.

Reliability and Validity Test has been applied to find out the extent of the reliable instrument of the research. Classical Assumption Test is used to obtain the value of the test which is efficient and not biased from the model of multiple linear equation. Classical Assumption Test contains of normality test, multicolinearity test, heteroscedasticity test.

Analitical technique that is used in this research is multiple regression analysis. Basically, multiple linear regression analysis which is used in a research aims to figure out the effects of more than two variables. This research has applied multiple regression analysis to measure the extent of the effects of independent variables (quality service and price) upon dependent variable (customer satisfaction)

\section{Result and Description}

As described on the definition of operational variables of this research such as Service Quality $\left(\mathrm{X}_{1}\right)$, Price $\left(\mathrm{X}_{2}\right)$, and Customers Satisfaction $(\mathrm{Y})$ that have been identified as follows:

\section{Validity Test}

Validity test is applied to find out the validity level of the instrument (questionnaires) that is used in the data collection obtained by correlating each score of the variable of respondent response with the total of each variable scores, then the result of its correlation is compared to the critical value at significant level of

Adri Wihananto. The effect of quality service and price upon the customers satisfaction (Case study at TIKI branch at Jl. K. H. Sholeh Iskandar Bogor) 
0.05 .

Table 1

Result of Validity Test of Quality Service

\begin{tabular}{|c|l|c|c|c|}
\hline No & $\begin{array}{l}\text { Quality } \\
\text { Service }\end{array}$ & $\mathbf{R}_{\text {count }}$ & Rtable & Description \\
\hline 1 & Statement 1 & 0.700 & 0.361 & Valid \\
\hline 2 & Statement 2 & 0.805 & 0.361 & Valid \\
\hline 3 & Statement 3 & 0.762 & 0.361 & Valid \\
\hline 4 & Statement 4 & 0.722 & 0.361 & Valid \\
\hline 5 & Statement 5 & 0.766 & 0.361 & Valid \\
\hline
\end{tabular}

Source : Primary Data processed

Referring to the result of the table above, it is concluded that each question of independent variable $(\mathrm{X} 1)$ is valid since the value of $r_{\text {count }}>r_{\text {table. }}$.

Table 2

Result of Validity Test of Price

\begin{tabular}{|c|c|c|c|c|}
\hline No & Price & $\mathbf{r}_{\text {count }}$ & rtabel & Description \\
\hline 1 & Statement 1 & 0.860 & 0.361 & Valid \\
\hline 2 & Statement 2 & 0.856 & 0.361 & Valid \\
\hline 3 & Statement 3 & 0.593 & 0.361 & Valid \\
\hline 4 & Statement 4 & 0.784 & 0.361 & Valid \\
\hline 5 & Statement 5 & 0.841 & 0.361 & Valid \\
\hline 6 & Statement 6 & 0.877 & 0.361 & Valid \\
\hline
\end{tabular}

Source : Primary Data processed

Referring to the result of the table above, it is concluded that each question of independent variable $(\mathrm{X} 2)$ is valid since the value of $r_{\text {count }}>r_{\text {table. }}$

Table 3

Test Result of Customers Satisfaction

\begin{tabular}{|c|l|c|c|c|}
\hline No & Price & $\boldsymbol{r}_{\text {count }}$ & $\boldsymbol{r}_{\text {table }}$ & Description \\
\hline 1 & Statement 1 & 0.723 & 0.361 & Valid \\
\hline 2 & Statement 2 & 0.743 & 0.361 & Valid \\
\hline 3 & Statement 3 & 0.785 & 0.361 & Valid \\
\hline 4 & Statement 4 & 0.779 & 0.361 & Valid \\
\hline
\end{tabular}


The Management Journal of BINANIAGA Vol. 04, No. 01, June 2019

p-ISSN: 2527 - 4317, e-ISSN: $2580-149 x$

$6^{\text {th }}$ Accreditation Rating: April 04, 2019- April 03, 2024

\begin{tabular}{|c|c|c|c|c|}
\hline No & Price & $r_{c o u n t}$ & $r_{\text {table }}$ & Description \\
\hline 5 & Statement 5 & 0.671 & 0.361 & Valid \\
\hline 6 & Statement 6 & 0.560 & 0.361 & Valid \\
\hline 7 & Statement 7 & 0.632 & 0.361 & Valid \\
\hline 8 & Statement 8 & 0.606 & 0.361 & Valid \\
\hline 9 & Statement 9 & 0.507 & 0.361 & Valid \\
\hline 10 & Statement 10 & 0.614 & 0.361 & Valid \\
\hline
\end{tabular}

Result of the table above has concluded that each question of independent variable $Y$ is valid since the value of $r_{\text {count }}>r_{\text {table. }}$

\section{Reliability Test}

Reliability test is done to find out the consistence of the respondents responses from time to time which is obtained by calculating alpha coefficient using alpha cronbach's method. If the result of $\alpha>0.06$ it means that the related intrument is high reliablity. The following is the the result of reliability test of each variable:

Table 4

Reliability Statistic

\begin{tabular}{|l|c|c|}
\hline \multicolumn{1}{|c|}{ Variabel } & $\begin{array}{l}\text { Critical } \\
\text { value }\end{array}$ & Conclusion \\
\hline Quality Service & 0.806 & 0.7 \\
\hline Price & 0.877 & 0.7 \\
\hline Customers Satisfaction & 0.856 & 0.7 \\
\hline
\end{tabular}

Referring to the value of alpha Cronbach's above, it is indicated that the variable of Service Quality (X1) which has been calculated by reliability test has indicated the value of 0.806 , price variable (X2) has identified the value of 0.877 and dependent variable which is Customers Satisfaction $(Y)$ has identified the value of 0.856 , it has explained that the value of alpha is bigger than the critical value of 0.6 . However, it can be concluded that measuring instruments which is the questionnaires are reliable. So that, the questionnaires can be applied for further analysis.

\section{Hypotheses Test}

\section{a. Analysis Result of Multiple Linear Regression}

Based on the calculation result of data processing using SPSS 20.00 computer program for windows, it has obtained the following multiple linear regression equation:

Adri Wihananto. The effect of quality service and price upon the customers satisfaction (Case study at TIKI branch at Jl. K. H. Sholeh Iskandar Bogor) 
Table 5

Analysis Result of Multiple Linear Regression

\begin{tabular}{|c|c|c|c|c|c|c|}
\hline \multirow{2}{*}{\multicolumn{2}{|c|}{ Model }} & \multicolumn{2}{|c|}{$\begin{array}{c}\text { Unstandardized } \\
\text { Coefficients }\end{array}$} & \multirow{2}{*}{$\begin{array}{c}\text { Standardized } \\
\text { Coefficients } \\
\text { Beta }\end{array}$} & \multirow{2}{*}{$\frac{t}{B}$} & \multirow{2}{*}{$\begin{array}{c}\text { Sig. } \\
\text { Std. Error }\end{array}$} \\
\hline & & B & Std. Error & & & \\
\hline 1 & (Constant) & 4.101 & 3.309 & & 1.239 & .217 \\
\hline & $\mathrm{X} 1$ & .737 & .107 & .435 & 6.886 & .000 \\
\hline & $\mathrm{X} 2$ & .816 & .121 & .425 & 6.723 & .000 \\
\hline
\end{tabular}

a Dependent Variable: $Y$

Based on the calculation result above, it has obtained the following multiple linear regression equation:

$Y=4.101+0.737 X_{1}+0.816 X_{2}$

The interpretations of the above regression model are as follows;

1) Constant $=4.10$ has identified the figure of customer satisfaction variable is not affected by variables of Quality Service (X1) and Price (X2) or independent variables $=0$, so that, the value of customers satisfaction is 4.101.

2) Coefficient value of Quality Service of 0.737 has identified that if the variable of Quality Service is increased, it is reflecting the increasing of Customers Satisfaction of 0.737 with the assumption that other variables are constant.

3) Coefficient value of Price 0.816 has idenfied that if the variable of price is increased which is in line with the quality provided, it reflects the increasing of Customers Satisfaction of 0.816 with the assumption that other variables are constant.

\section{b. Determinant Coefficient}

Table 6

Determinant Coefficient

Model Summary

\begin{tabular}{|l|c|c|c|c|}
\hline Model & $\mathrm{R}$ & $\mathrm{R}$ Square & $\begin{array}{c}\text { Adjusted R } \\
\text { Square }\end{array}$ & $\begin{array}{c}\text { Std. Error of } \\
\text { the Estimate }\end{array}$ \\
\hline 1 & $.707(\mathrm{a})$ & .499 & .492 & 2.100 \\
\hline
\end{tabular}

a Predictors: (Constant), price, Quality Service

Coefficient value of Correlation $(\mathrm{R})$ has identified the extent of the correlation between independent variables (Quality Service Variable and Price Variable) and dependent variable (Customers Satisfaction), and the coefficient value of correlation is 0.499 . This value has indicated that the correlation of quality service variable and price variable with customers satisfaction variable is strong which is $49.9 \%$. 


\section{Hypotheses Proven}

\section{a. Test of Individual Parameter Significance $\left(T_{\text {test }}\right)$}

Hypotheses proven has applied test (partial test) to identify whether service quality and price individually have affected customers satisfaction. The output of SPSS test is as the following:

Table 7

Coefficients(a)

\begin{tabular}{|l|l|l|r|}
\hline \multicolumn{2}{|l|}{ Model } & \multirow{2}{*}{$\mathrm{T}$} & \multirow{2}{*}{ Sig. } \\
\hline \multicolumn{2}{|l|}{} & & \\
\hline 1 & (Constant) & 1.239 & .217 \\
\hline & $\mathrm{X} 1$ & 6.886 & .000 \\
\hline & $\mathrm{X} 2$ & 6.723 & .000 \\
\hline
\end{tabular}

Referring to the table above, result of test can be described as follows:

1) Quality Service variable has the value of tcount of 6.886 , but table at $5 \%$ probability is 1.960. Therefore, since the calculation of $t_{\text {count }}>$ table $(6.886>1.960)$ with sig.value of $0.000<5 \%(0.05)$, it has explained that quality service variable statistically has affected significantly customers satisfaction. Nevertheless the hypotheses of this research is accepted.

2) Price variable has the value of $t_{\text {count }}$ of 6.723 , but table at the probability of $5 \%$ is 1.960. Therefore, since $t_{\text {count }}>t_{\text {table }}(6.723>1.960)$ with sig.value of $0.000<5 \%$ $(0.05)$, it has explained that the variable of price statistically has affected significantly the customers satisfaction. Nevertheless the hypotheses of this research is accepted.

b. Test of Simultaneous Significance ( $F$ test)

Hypotheses proven has applied test (simultaneous test) to find out wheter quality service and price simultaneously have affected customers satisfaction. Output of SPSS test as follows;

Table 8

ANOVA(b)

\begin{tabular}{|l|l|r|r|r|r|r|}
\hline \multicolumn{2}{|l|}{ Model } & \multicolumn{1}{|c|}{$\begin{array}{l}\text { Sum of } \\
\text { Squares }\end{array}$} & \multicolumn{1}{c|}{$\mathrm{df}$} & $\begin{array}{l}\text { Mean } \\
\text { Square }\end{array}$ & $\mathrm{F}$ & Sig. \\
\hline 1 & Regression & 628.819 & 2 & 314.410 & 71.270 & $.000(\mathrm{a})$ \\
\hline & Residual & 630.852 & 143 & 4.412 & & \\
\hline & Total & 1259.671 & 145 & & & \\
\hline
\end{tabular}

a Predictors: (Constant), X2, X1 b Dependent Variable: $Y$

Based on the table above, it has identified that the value of $F_{\text {count }}$ obtained in this model is 71.270 , but $F_{\text {table }}$ df: $\alpha,(k-1),(n-k)=0.05,(2-1),(146-3)$ is 4.60 . Therefore, since $F_{\text {count }}>F_{\text {table }}(71.270>4.60)$ with sig.value of $0.000<5 \%(0.05)$, it has declared that quality service variable and price variable statistically and simultaneously have affected significantly the variable of customers satisfaction. Nevertheless the hypotheses of this research is accepted. 


\section{Conclusion and Suggestions}

Based on the result and description of the research above, it can be concluded that:

1. There is a significant effect of the variable quality service upon the variable of customers satisfaction. It has been identified by the value of tcount of 6.886 , and table at the probability of $5 \%$ is 1.960 . Since $t_{\text {count }}>$ t table $(6.886>1.960)$ with sig.value of $0.000<5 \%$ $(0.05$, it has explained that partially the variable of quality service has affected significantly the variable of customers satisfaction.

2. There is a significant effect of price variable upon the customers satisfaction variable. It has been identified by tcount of 6.723 , and table at the probability of $5 \%$ is 1.960 . Since tcount $>$ table $(6.723>1.960)$ with sig. Value of $0.000<5 \%(0.05)$, it has identified that partially the variable of quality service has affected significantly the variable of customers satisfaction.

3. There is the effect of quality service variable and price variable upon the variable of customers satisfaction. It has been identified by the value of $F_{\text {count }}$ of 71.270 , and $F_{\text {table }}$ df $: \alpha,(k-1),(n-k)=0.05,(2-1),(146-3)$ is 4.60 . Since $F_{\text {count }}>F_{\text {table }}(71.270>4.60)$ with sig.value of $0.000<5 \%(0.05)$, it has determined that statistically the variable of quality service and the variable of price simultaneously have affected the variable of customers satisfaction. It has explained that the quality service and price positively can increase the customers satisfaction at PT TIKI Bogor Branch at JI. K. H. Sholeh Iskandar Bogor.

However, the suggestion that can be offered based on the result of the research is as since the quality service variable and price variable have affected positively the customers satisfaction, PT TIKI should have improved continuously both variables above in order to maintain and to improve its customers satisfaction. Quality Service can be increased by improving continously the quality of its human resources and by doing innovation to improve the value of facility which is supporting the quality service. PT TIKI Brand at JI. K. H. Sholeh Iskandar Bogor should have to be concerned with the price perception of the customers. Since the affordable price which is in compliance with the quality service given will be competing other service companies and it will be affectting the customers satisfaction obviously.

\section{References}

Dharmesta, I. (2008). Manajemen Pemasaran Modern. Edisi Kedua. Yogyakarta, Liberty.

Ellena. (2011). Analisis Pengaruh Kepercayaan, Komitmen, Komunikasi, dan Penanganan Keluhan terhadap Loyalitas Nasabah (Studi pada Nasabah PT. BRI (Persero) tbk. Cabang Pemalang. Skripsi Universitas Diponegoro Semarang.

Kotler, P., Keller, K. L. (2008). Manajemen Pemasaran. Edisi Ketiga Belas, Jakarta: Prenhalindo.

Kotler, P., (2010). Manajemen Pemasaran, Jakarta: Edisi Millenium, Prehallindo.

Lamb, W.C.., Hair, F.J., Daniel, M.C., Carl. (2011). Pemasaran. Edisi pertama. Jakarta: Salemba Empat.

Schiffman, L., Kanuk, L.K. (2009), Perilaku onsumen, PT. Index.

Sugiyono. (2016). Statistika untuk Penelitian, Bandung: Alfabeta.

Tjiptodjojo, K.I. (2013). Odd Price: Harga, Psikologi dan Perilaku Konsumen dalam Purchase Decision Making, Jurnal Manajemen,11(2). 
The Management Journal of BINANIAGA Vol. 04, No. 01, June 2019

p-ISSN: 2527 - 4317, e-ISSN: $2580-149 x$

$6^{\text {th }}$ Accreditation Rating: April 04, 2019-April 03, 2024

Tjiptono, F. (2011). Strategi Pemasaran. Yogyakarta: Andi Offset,

(2008). Strategi Bisnis Pemasaran. Yogyakarta: Andi Offset.

(2010). Prinsip-Prinsip Total Quality Service. Yogyakarta. Andi Offset.

(2014). Manajemen Jasa. Edisi I. Yogyakarta. Penerbit Andi Offset.

Umar, H. (2009), Riset Pemasaran dan Prilaku Konsumen, Jakarta: PT Gramedia. 